\title{
PROFIL AKTIVITAS ANTIBAKTERI EKSTRAK KULIT SALAK TERHADAP PERTUMBUHAN BAKTERI Salmonella typhi
}

\author{
Lulu Setiyabudi*1, Irvan Herdiana ${ }^{2}$, Wildan Hilmi ${ }^{3}$ \\ ${ }^{1}$ Program Studi S1 Farmasi, STIKES Al-Irsyad Al-Islamiyyah Cilacap \\ ${ }^{2,3}$ Program Studi D3 Farmasi, Jurusan Farmasi, Poltekkes Kemenkes Tasikmalaya \\ ${ }^{1} e$-mail: ${ }^{1 * 1}$.setiyabudi@gmail.com, 2,3 wildanhilmi1234@gmail.com
}

\begin{abstract}
ABSTRAK
Sebagian besar masyarakat menganggap bahwa kulit salak merupakan limbah yang tidak bisa digunakan.Masyarakat hanya memanfaatkan buah salak dari bagian dagingnya saja, bagian lainnya seperti kulit buah salak belum dimanfaatkan dengan baik. Kulit salak memiliki kandungan senyawa metabolit sekunder yang memiliki manfaat sebagai alternatif pengobatan, dan berpotensi memiliki aktivitas antibakteri.Penelitian ini bertujuan untuk mengetahui aktivitas antibakteri dalam ekstrak etanol kulit salak terhadap bakteri Salmonella typhi. Kulit buah salak diekstraksi menggunakan pelarut etanol 70\% dengan metode maserasi. Aktivitas antibakteri ekstrak etanol kulit salak diuji terhadap bakteri Salmonella typhi dengan menggunakan metode difusi cakram kertas.Ekstrak etanol kulit salak dapat menghambat pertumbuhan Salmonella typhi. Semakin besar konsentrasi ekstrak, diameter zona bening yang terbentuk semakin luas. Aktivitas antibakteri palingefektifpada konsentrasi 20\%. Kandungan metabolit sekunder yang terdapat dalam ekstrak kulit salak berupa alkaloid, flavonoid, polifenol, tanin, dan kuinon.
\end{abstract}

Kata kunci: kulit salak, antibakteri, Salmonella typhi

\begin{abstract}
The most of peoples assuming that peel of snake fruit (Salacca zalacca) is just a rubbish, Peoples just consume flesh of snake fruit, other parts such as peel has not used properly and thrown away. The peel of snake fruit containing secondary metabolite compounds which have the benefits of an alternative treatment, and potentially have antibacterial activity. The aim of this study to determine the antibacterial activity in the salak ethanol extract against the growth of Salmonella typhi. Snake fruit's peel was extracted using 70\% ethanol solvent by maceration method. Antibacterial activity of ethanolic extract from peel of snake fruits was tested against Salmonella typhi using disc diffusion test method.Ethanolic extract from peel of snake fruits can inhibit the growth of Salmonella typhi. The greater the concentration of the extract, the clearer diameter of the cleared zone. The most effective to inhibit is at $20 \%$ Secondary metabolite contained in snake fruit's peel extract are alkaloids, flavonoids, polyphenols, tannins, and quinones.
\end{abstract}

Keywords: snake fruit's peel, antibacteria, Salmonella typhi

\section{PENDAHULUAN}

Indonesia merupakan negara beriklim tropis yang memiliki banyak keanekaragaman, salah satunya yaitu tanaman. Pemanfaatan tanaman oleh masyarakat sebagai pengobatan sudah dilakukan secara turun-temurun. Hal ini disebabkan adanya anggapan bahwa obat herbal memiliki efek samping yang lebih kecil. Banyak jenis tanaman yang telah digunakan sebagai bahan obat, salah satunya adalah salak. Salak (Salacca zalacca)merupakan buah yang cukup digemari dan masyarakat memanfaatkan buahnya untuk mengobati diare [1].

Hingga saat ini, masyarakat hanya memanfaatkan bagian dari buah salak saja, sedangkan bagian dari kulit salak masih belum banyak dimanfaatkan. Kulit salak merupakan limbah yang biasanya tidak digunakan lagi, tetapi sebagian kecil masyarakat menggunakan kulit salak sebagai obat anti diabetes [2]. Kulit salak juga telah dimafaatkan sebagai teh yang kaya 
antioksidan [3]. Selain itu, kombinasi kulit salak dan biji kurma mampu menurunkan kadar asam lemak bebas dari $1,768 \%$ menjadi $0,358 \%$ [4]. Berdasarkan penelitian yang telah dilakukan sebelumnya, kulit buah salak memiliki kandungan senyawa alkaloid, polifenolat, flavonoid, tanin, kuinon, monoterpen dan sesquiterpen dengan parameter standar simplisia nonspesifik berupa kadar air sebesar 13,25\%, kadar abu total sebesar 5,61\% dan kadar abu tidak larut asam sebesar 0,50\% [5]. Beberapa senyawa metabolit sekunder dalam kulit salak dipercaya memiliki aktivitas sebagai antibakteri.

Salmonella typhi berbentuk batang dengan flagella peritrik, tidak berspora. Bakteri ini menyebabkan luka meradang pada usus besar dan kecil, merupakan bakteri yang paling banyak menginfeksi manusia. Salmonella typhi mempunyai kemampuan untuk melalui asetilasi antigen-O yang mengubah konformasi, dan membuat Salmonella typhi sulit untuk dikenali antibodi [6]. Bakteri Salmonella memiliki sifat sebagai patogen bagi manusia atau hewan melalui jalur oral. Salmonella dapat tumbuh pada media sederhana, namun hampir tidak pernah memfermentasi laktosa atau sukrosa. Salmonella typhi mampu membentuk asam dan terkadang membentuk gas dari glukosa dan manosa. Mereka umumnya menghasilkan $\mathrm{H}_{2} \mathrm{~S}$. Organisme ini dapat bertahan hidup pada air yang beku untuk periode yang lama [7].

Salmonella tumbuh pada suasana aerob dan fakultatif anaerob, pada suhu $15-41^{\circ} \mathrm{C}$ (suhu pertumbuhan optimum $37,5^{\circ} \mathrm{C}$ ) dan $\mathrm{pH}$ pertumbuhan $6-8$. Salmonella mati pada suhu $56^{\circ} \mathrm{C}$ juga pada keadaan kering. Dalam air bisa tahan selama 4 minggu. Hidup subur pada media yang mengandung garam empedu, tahan terhadap zat warna hijau brilian dan senyawa natrium tetrationat, dan natrium deoksikholat [8].

Bakteri Salmonella typhi merupakan salah satu penyebab terjadinya demam tifoid. Demam tifoid adalah penyakit infeksi serius. Penyakit endemis ini telah menjadi masalah kesehatan global termasuk di Indonesia dan negara-negara Asia Tenggara seperti Malaysia dan Thailand. Pengobatan demam tifoid beranekaragam mulai dari penggunaan antibiotik hingga menggunakan pengobatan tradisional yang memanfaatkan tanaman obat di daerah setempat [9]. Salah-satu antibiotik yang digunakan sebagai obat terapi pilihan pertama adalah kloramfenikol. Kloramfenikol merupakan salah satu antibiotik yang memiliki spektrum luas dan sensitif terhadap bakteri gram negatif. Berdasarkan keefektivitasnya terhadap Salmonella typhi obat tersebut juga relative murah dan penggunaannya cukup tinggi dalam pengobatan demam tifoid, sehingga perlu diupayakan suatu pengobatan alternatif antibakteri.

\section{METODE PENELITIAN}

Penelitian ini termasuk jenis eksperimental laboratorium. Uji aktivitas antibakteri yang digunakan penelitian ini adalah metode difusi cakram kertas.

\subsection{Alat dan Bahan}

Alat yang digunakan dalam penelitian ini adalah neraca analitik Ohauss (Pioneer ${ }^{\mathrm{TM}}$ ), autoklaf (GEA model YX-18LM), inkubator (Memmert), mikropipet (Socorex), hotplate (CMAG-HS7 IKA), dan alat-alat gelas lain yang biasa digunakan di laboratorium. Bahan yang digunakan dalam penelitain ini adalah etanol 70\% (Brataco), methanol (Brataco), aquadest (Brataco), $\mathrm{NaCl}$ (Brataco), $\mathrm{BaCl}_{2}$ (Brataco), $\mathrm{H}_{2} \mathrm{SO}_{4}$ (Brataco), Bakto agar(Oxoid), Tryptone Soya Broth (Oxoid), kristal violet (Merck), iodium (Brataco), safranin (Merck).

\subsection{JalannyaPenelitian}

Jalannya penelitian diawali dengan preparasi sampel, determinasi kulit salak, pembuatan ekstrak kulit salak, dan skrining fitokimia yang meliputi uji alkaloid, flavonoid, saponin, tanin, polifenol, kuinon, mono/seskuiterpen, dan steroid. Selanjutnya, uji aktivitas antibakteri terhadap Shalmonella typhi dengan variasi konsentrasi ekstrak $(1,3,5,10,20,40$, dan 80\%). Pada uji aktivitas antibakteri digunakan kontrol positif berupa amoksilin $25 \mu \mathrm{g}$ dan kontrol negatif kertas cakram yang telah direndam dalam etanol $70 \%$. 
Kulit salak (Salacca zalacca) dengan varietas Manonjaya didapatkan dari Sentra Salak di Cibeureum Kota Tasikmalaya. Determinasi kulit salak dilakukan dengan mengirimkan sampel ke Jurusan Biologi Fakultas Keguruan dan Ilmu Pendidikan Universitas Siliwangi. Pembuatan ekstrak kulit buah salak dilakukan dengan metode maserasi, yaitu kulit salak segar yang telah disortasi dibersihkan lalu ditimbang sebanyak $200 \mathrm{~g}$ lalu diekstraksi dengan menggunakan $2000 \mathrm{~mL}$ etanol 70\% dengan cara maserasi selama 3x24 jam (setiap 24 jam pelarut diganti dan diaduk). Setelah itu dilakukan penyaringan menggunakan kertas saring, filtrat dikumpulkan lalu dipekatkan menggunakan rotary evaporator dengan suhu $70^{\circ} \mathrm{C}$. Skrining fitokimia dilakukan dengan mengencerkan ekstak kental lalu dibagi kedalam beberapa tabung reaksi untuk uji alkaloid dengan reagen Meyer dan Dragendorff, uji flavonoid dengan logam $\mathrm{Mg}$ dan asam klorida, uji saponin, uji polifenol dengan reagen $\mathrm{FeCl}_{3}$, uji tanin dengan reagen gelatin $1 \%$, uji kuinon dengan reagen $\mathrm{NaOH}$, serta uji steroid dan terpenoid dengan reagen Liebermann Burchad.

Uji alkaloid dilakukan dengan penambahan 10- 20 tetes $\mathrm{H}_{2} \mathrm{SO}_{4} 2 \mathrm{~N}$. Campuran dikocok dengan teratur selama 2-3 menit, dibiarkan beberapa sampai terbentuk 2 lapisan. Lapisan atas dipindahkan ke dalam tiga tabung reaksi masing-masing sebanyak $1 \mathrm{ml}$. Kemudian masingmasing tabung tersebut ditambahkan beberapa tetes pereaksi Mayer dan Dragendorff. Terbentuknya endapan putih terhadap pereaksi Mayer, dan endapan merah terdahap pereaksi Dragendorff. Uji flavonoid dilakukan dengan penambahan beberapa tetes $\mathrm{HCl}$ pekat. Kemudian ditambahkan bubuk Mg. Hasil positif ditunjukkan dengan timbulnya warna merah tua [10].

Uji saponin dilakukan dengan dilakukan pengocokan ekstrak selama \pm 10 detik. Selanjutnya, ditambahkan $\mathrm{HCl} 2 \mathrm{~N}$ dan dikocok lagi. Hasil uji positif terbentuk buih di permukaan. Uji polifenol dilakukan dengan penambahan 2-3 tetes larutan $\mathrm{FeCl}_{3}$ 1\%. Hasil positif ditunjukkan dengan terbentuknya warna hitam. Uji tanin dilakukan dengan penambahan larutan gelatin 1\%. Adanya tanin ditandai dengan terbentuknya endapan berwarna putih. Uji kuinon dilakukan dengan penambahan reagen $\mathrm{NaOH}$. Adanya kuinon ditandai dengan larutan berwarna kuning hingga merah. Uji steroid dan terpenoid dilakukan dengan reagen Libermann Burchard. Hasil positif ditunjukkan dengan perubahan warna larutan dari ungu atau merah menjadi biru atau hijau [10].

Uji aktivitas antibakteri dilakukan dengan difusi kertas cakram. Kertas cakram yang sudah disiapkan diletakkan di atas media yang telah diinokulasi Salmonella typhi. Selanjutnya, media diinkubasi selama 18-24 jam. Zona hambat yang terbentuk diukur diameternya.

\subsection{Analisis Data}

Metode analisis data yang dilakukan adalah statistik desktiptif yaitu untuk melihat keberadaan perbandingan kemampuan ekstrak menghambat aktivitas pertumbuhan bakteri. Data yang ditampilkan adalah data numerik berupa persentase daya hambat masing-masing konsentrasi ekstrak.

\section{HASIL DAN PEMBAHASAN}

Pengambilan ekstrak kulit salak dilakukan secara maserasi. Maserasi dilakukan dengan cara merendam serbuk simplisia kulit salak kedalam pelarut etanol $70 \%$. Pelarut akan menembus dinding sel dan masuk ke dalam rongga sel yang mengandung zat aktif, zat aktif akan larut dan karena adanya perbedaan konsentrasi antara larutan zat aktif di dalam sel dengan yang di luar sel, maka larutan yang terpekat akan didesak keluar. Peristiwa tersebut berulang sehingga terjadi keseimbangan konsentrasi antara larutan di luar sel dan di dalam sel. 36. Maserasi sampel dilakukan dengan menggunakan pelarut etanol karena sifatnya yang mampu melarutkan hampir semua zat, baik yang bersifat polar, semi polar dan non polar serta kemampuannya untuk mengendapkan protein dan menghambat kerja enzim sehingga dapat 
terhindar dari proses hidrolisis dan oksidasi. Etanol sangat efisien untuk ekstraksi dari berbagai konstituen tanaman [11].

Hasil filtrat pertama, kedua dan yang ketiga dari proses ekstraksi etanol kulit salak dipisahkan dengan pelarutnya menggunakan Rotary Evaporator yang pada penelitian ini menggunakan pelarut etanol yang digunakan saat merendam simplisia kulit salak dan kemudian menggunakan waterbath dengan tujuan melakukan pemekatan untuk membuat ekstrak etanol kulit salak menjadi kental. Penguapan dapat terjadi karena adanya pemanasan. Prinsip kerja Rotary Evaporator adalah menguapkan larutan etanol yang terdapat dalam ekstrak etanol kulit salak dengan suhu yang tidak terlalu tinggi yaitu $70^{\circ} \mathrm{C}$ kemudian suhu pada saat pemekatan menggunakan Waterbath menggunakan suhu $70^{\circ} \mathrm{C}$

Hasil Ekstrak kental yang didapatkan sebanyak 7,42 gr dengan nilai rendemen ekstrak sebesar 3,71\% dari 200 gr kulit salak. Karakteristik ekstrak kental kulit salak adalah berbentuk semi padat dengan rasa pahit. Skrining fitokimia memberikan hasil bahwa ekstrak kulit salak positif mengandung senyawa alkaloid, flavonoid, polifenol, tanin, dan kuinon. Akan tetapi menunjukkan hasil negatif untuk golongan senyawa saponin, steroid/triterpenoid, dan monoterpenoid/seskuiterpenoid.

Tabel I. Hasil skrining fitokimia ekstrak kulit salak

\begin{tabular}{cllc}
\hline No. & \multicolumn{1}{c}{ Pemeriksaan } & \multicolumn{1}{c}{ Pereaksi } & Hasil \\
\hline 1. & Alkaloid & Reagen Meyer & $(+)$ \\
& & Reagen Dragendorff & $(+)$ \\
2. & Flavonoid & $\mathrm{HCl}$, serbuk $\mathrm{Mg}$ & $(+)$ \\
3. & Kuinon & $\mathrm{NaOH} 2 \mathrm{M}$ & $(+)$ \\
4. & Polifenol & $\mathrm{FeCl}_{3}$ & $(+)$ \\
5. & Tanin & $\mathrm{Gelatin} 1 \%$ & $(+)$ \\
6. & Steroid/Triterpenoid & Liebermann Burchard & $(-)$ \\
7. & Monoterpenoid/Seskuiterpenoid & Vanillin, $\mathrm{H}_{2} \mathrm{SO}_{4}$ & $(-)$ \\
8. & Saponin & $\mathrm{HCl}$ dikocok & $(-)$ \\
\hline
\end{tabular}

Pengujian senyawa alkaloid dengan reagen Meyer menghasilkan endapan putih. Hasil tersebut mengindikasikan adanya nitrogen pada senyawa alkaloid yang bereaksi dengan ion logam $\mathrm{K}^{+}$dari kalium tetradiomerkurat (II) membentuk kompleks kalium-alkaloid yang mengendap. Pengujian senyawa alkaloid lainnya dengan reagen Dragendorff menghasilkan endapan berwarna coklat. Hasi ltersebut menunjukkan adanya nitrogen pada alkaloid yang bereakasi dengan ion logam $\mathrm{K}^{+}$dari kalium tetraiodobismutat membentuk kompleks kaliumalkaloid. Hal ini menunjukkan bahwa ekstrak mengandung senyawa alkaloid [12]. Pada pengujian senyawa flavonoid dengan serbuk $\mathrm{Mg}, \mathrm{HCl}$ pekat dan amil alkohol menghasilkan larutan berwarna kuning pada lapisan amil alkohol. Hasil tersebut mengindikasikan logam $\mathrm{Mg}$ dan $\mathrm{HCl}$ pekat mereduksi inti benzopiron pada struktur flavonoid, sehingga terbentuk garam flavilium. Hasil ini menunjukkan ekstrak mengandung senyawa flavonoid [13].

Selanjutnya, pengujian senyawa polifenol dengan reagen $\mathrm{FeCl}_{3}$ menghasilkan larutan berwarna hitam. Hasil tersebut mengindikasikan reaksi $\mathrm{FeCl}_{3}$ dengan gugus $-\mathrm{OH}$ aromatis. Kompleks berwarna yang terbentuk diduga sebagai besi (III) heksafenolat yang berwarna merah, ungu, biru, atau hitam pekat. Hal ini menunjukkan ekstrak mengandung senyawa polifenol [14]. Pengujian senyawa tanin dengan larutan gelatin $1 \%$ menghasilkan endapan berwarna putih. Hasil tersebut diperkirakan tanin mengendapkan protein gelatin membentuk kopolimer dan tidak larut air. Hal ini menunjukkan ekstrak mengandung senyawa tanin. Pengujian senyawa kuinon menggunakan $\mathrm{NaOH} 2 \mathrm{~N}$ menghasilkan larutan kuning yang menunjukkan ekstrak mengandung senyawa kuinon.

Uji aktivitas antibakteri dilakukan dengan metode difusi cakram kertas (diameter 6 $\mathrm{mm}$ ). Aktivitas antibakteri ditunjukkan dengan adanya zona bening yang terbentuk di sekitar kertas cakram. Semakin lebar diameter zona bening yang terbentuk, maka sifat aktivitas 
antibakteri suatu senyawa semakin kuat. Uji antibakteri bertujuan untuk mengetahui aktivitas antibakteri ekstrak kulit salak. Dalam penelitian ini, media yang digunakan yaitu Tryptone Soya Broth dalam Agar bacteriological yang dipadatkan dalam petri. Pengujian aktivitas antibakteri dilakukan sebanyak 3 kali dengan rentang konsentrasi ekstrak kulit salak 20\%, 40\%, dan 80\%. Pada rentang konsentrasi ini menunjukkan adanya zona bening di sekitar cakram yang menunjukkan adanya hambatan terhadap pertumbuhan Salmonella typhi seperti yang dapat dilihat pada gambar 1.

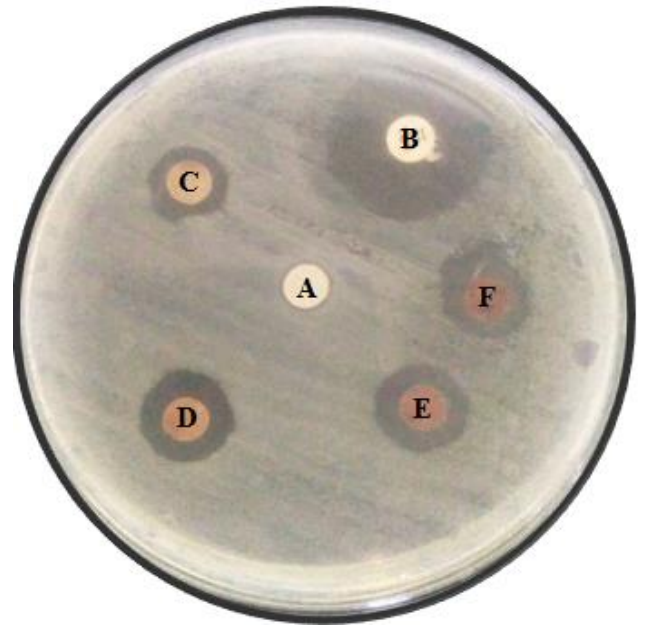

Gambar 1. Zona hambat ekstrak kulit salak terhadap pertumbuhan Shalmonella typhi. A (kontrol negatif), B (kontrol positif), C-F (ekstrak konsentrasi $10,20,40,80 \%$ )

Setelah dilakukan pengujian aktivitas antibakteri pada konsentrasi ekstrak 10\%, 20\%, $40 \%$, dan $80 \%$, kemudian konsentrasi diperkecil sehingga didapat diameter zona hambat pada konsentrasi 1\%, 3\%, dan 5\%. Pada konsentrasi tersebut menunjukkan zona bening yang menunjukkan adanya aktivitas ekstrak kulit salak yang menghambat pertumbuhan bakteri Salmonella typhi. Tahapan memperkecil konsentrasi bertujuan untuk mengetahui Konsentrasi Hambat Minimum (KHM) dan pengaruh konsentrasi ekstrak etanol kulit salak terhadap pertumbuhan bakteri. Hasil pengamatan menunjukkan adanya zona hambat dengan diameter zona hambat yang berbeda di tiap konsentrasinya. Pengukuran diameter zona hambat menggunakan jangka sorong. Hasil pengamatan dapat dilihat pada tabel II.

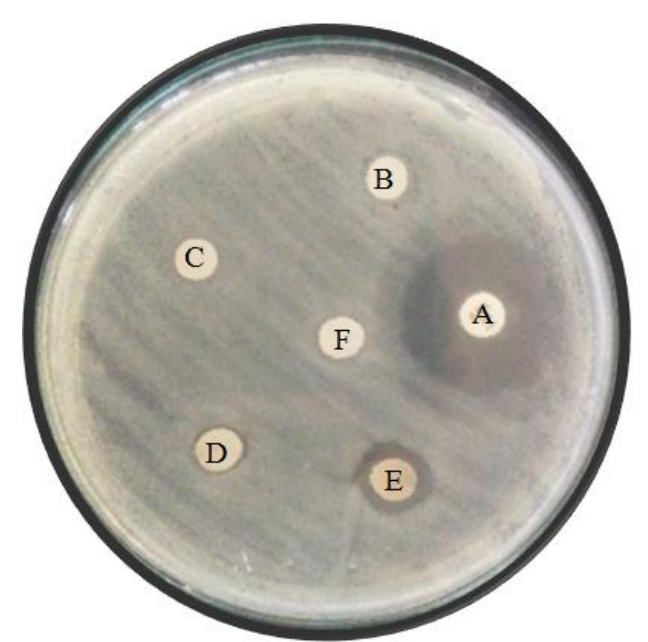

Gambar 2. Zona hambat ekstrak kulit salak terhadap pertumbuhan Shalmonella typhi. A (kontrol positif), B-E (ekstrak konsentrasi 3, 5, $10 \%), F$ (kontrol negatif) 
Secara keseluruhan, pengujian aktivitas antibakteri dilakukan sebanyak 3 kali dengan rentang konsentrasi ekstrak kulit salak 1\%, 3\%, 5\%, 10\%, 20\%, 40\%, dan 80\%, amoksisilin 25 $\mu \mathrm{g}$ sebagai kontrol positif, dan metanol $70 \%$ sebagai kontrol negatif. Pada rentang konsentrasi ini menunjukkan adanya zona bening dengan diameter yang berbeda, yaitu $0 \mathrm{~mm}$ untuk kontrol negatif dan konsentrasi ekstrak 1\%. Hal ini menunjukkan tidak adanya hambatan terhadap pertumbuhan Salmonella typhi. Akan tetapi, pada konsentrasi 3, 5, 10, 20, 40, dan 80 \% terdapat zona bening dengan masing-masing diameter sebesar $0,53 \mathrm{~mm}, 2,11 \mathrm{~mm}, 5,37 \mathrm{~mm}, 6,42 \mathrm{~mm}$, $6,77 \mathrm{~mm}$, dan 7,04 mm. Untuk kontrol positif dihasilkan zona bening dengan diameter sebesar $18,6 \mathrm{~mm}$.

Tabel II. Diameter zona hambat terhadap pertumbuhan Shalmonella typhi

\begin{tabular}{lccc}
\hline \multicolumn{1}{c}{ Sampel } & $\begin{array}{c}\text { Rata-rata diameter } \\
\text { zona hambat }(\mathbf{m m})\end{array}$ & $\begin{array}{c}\text { Standar } \\
\text { Deviasi }\end{array}$ & $\begin{array}{c}\text { Respon Hambatan } \\
\text { Pertumbuhan }\end{array}$ \\
\hline Ekstrak kulit salak 1\% & 0 & 0,00 & Tidak Ada Hambatan \\
Ekstrak kulit salak 3\% & 0,53 & 0,25 & Lemah \\
Ekstrak kulit salak 5\% & 2,11 & 0,39 & Lemah \\
Ekstrak kulit salak 10\% & 5,37 & 0,02 & Sedang \\
Ekstrak kulit salak 20\% & 6,42 & 0,11 & Kuat \\
Ekstrak kulit salak 40\% & 6,77 & 0,18 & Kuat \\
Ekstrak kulit salak 80\% & 7,04 & 0,53 & Kuat \\
\hline Kontrol positif & 18,6 & 0,11 & Kuat \\
(Amoksisilin 25 $\mu \mathrm{g})$ & & & Tidak Ada hambatan \\
Kontrol negatif & 0 & 0,00 & \\
(Metanol70\%) & & &
\end{tabular}

Nilai standar deviasi pada penelitian ini digunakan untuk mengetahui homogenitas dari setiap data. Berdasarkan hasil yang telah didapat, nilai standar deviasi dari masing-masing konsentrasi tidak lebih dua kali dari nilai mean dan memiliki variasi yang tidak terlalu besar. Hasil ini menunjukkan sebaran data pengulangan baik. Kontrol positif yang digunakan dalam penelitian ini berupa disc amoksisilin $25 \mu \mathrm{g}$. Diameter zona hambat dengan nilai rata-rata sebesar $18.6 \mathrm{~mm}$ yang menunjukkan respon hambatan pertumbuhan kuat. Kontrol negatif yang digunakan adalah metanol $70 \%$ serta diperoleh diameter zona hambat $0 \mathrm{~mm}$. Hal ini menunjukkan tidak adanya aktivitas daya hambat dalam etanol 70\%. Metanol 70\% digunakan karena metanol $70 \%$ mampu melarutkan ekstrak kental kulit salak dan tidak menghambat pertumbuhan bakteri Salmonella typhi.

Ekstrak kulit salak memiliki nilai efisiensi yang berbeda terhadap aktivitas kontrol positif di tiap rentang konsentrasinya yaitu $0 \% ; 2,83 \% ; 11,36 \% ; 28,89 \% ; 34,51 \% ; 36,38 \%$; dan $37,85 \%$. Nilai efisiensi tersebut menunjukkan kesetaraan terhadap aktivitas kontrol positif yang digunakan. Aktivitas antibakteri dari ekstrak kulit salak dapat dihubungkan dengan adanya senyawa metabolit sekunder yang terkandung dalam ekstrak kulit salak berupa senyawa alkaloid, flavonoid, polifenol, tanin, dan kuinon. Nilai efisiensi yang masih sangat jauh dibandingkan kontrol positif. Hal ini disebabkan senyawa metabolit sekunder yang didapatkan dari ekstrak etanol biji Kamandrah belum spesifik untuk menghambat pertumbuhan Salmonella typhi sehingga senyawa alkaloid, tanin, saponin, flavonoid, dan steroid tidak dapat menembus dinding Salmonella typhi yang tersusun lipoprotein, fosfolipid, dan lipopolisakarida. Senyawa yang memiliki aktivitas antibakteri dan dapat merusak dinding sel bakteri adalah senyawa turunan tanin salah satunya tanin hidrolisis [15]. Menurut More et al fraksi alkaloid terisolasi tidak dapat melawan bakteri gram negatif. Hal ini disebabkan karena membran luar bakteri negatif memiliki barrier penetrasi berbagai molekul antibakteri dan ruang periplasma mengandung enzim yang mampu mendegradasi molekul eksogen [16].

Menurut Bhuiyan et al., senyawa flavonoid golongan isoflavon memiliki memiliki aktivitas antibakteri karena adanya gugus fenol [17]. Menurut Hassan, saponin diklasifikasikan 
menjadi saponin triterpenoid dan saponin steroid. Susunan senyawa saponin steroid terdiri atas inti steroid dengan memiliki molekul karbohidrat. Saponin steroid memiliki suatu aglikon dikenal sebagai saraponin dari proses hirolisis. Saponin triterpenoid memiliki susunan inti triterpenoid dengan molekul karbohidrat yang memiliki suatu aglikon yang disebut sebagai sapogenin dari proses hidrolisis. Tipe saponin ini adalah turunan $\beta$-amyirine yang dapat menurunkan tegangan permukaan dinding sel bakteri [18]. Menurut Hyldgaard, turunan senyawa steroid (terpenoid) adalah golongan monoterpenoid seperti carvacrol dan thymol yang dapat melisiskan membran sel bakteri [19].

Golongan senyawa metabolit sekunder tersebut masing-masing memiliki mekanisme kerja aktivitas antibakteri. Mekanisme alkaloid sebagai antibakteri yaitu dengan cara mengganggu komponen penyusun peptidoglikan pada sel bakteri sehingga lapisan dinding sel tidak terbentuk secara utuh dan menyebabkan kematian sel.Mekanisme kerja flavonoid sebagai antibakteri adalah membentuk senyawa kompleks dengan protein ekstraseluler dan terlarut sehingga dapat merusak membrane sel bakteri dan diikuti dengan keluarnya senyawa intraseluler. Flavonoid juga berperan dalam menghambat metabolisme energi. Senyawa ini akan mengganggu metabolisme energi dengan cara yang mirip dengan menghambat sistem respirasi, karena dibutuhkan energi yang cukup untuk penyerapan aktif berbagai metabolit dan untuk biosintesis makromolekul [20].

Mekanisme kerja tanin sebagai antibakteri adalah menghambat enzim reverse transkriptase dan DNA topoisomerase sehingga sel bakteri tidak dapat terbentukTanin memiliki aktivitas antibakteri yang berhubungan dengan kemampuannya untuk menginaktifkan adhesin sel mikroba juga menginaktifkan enzim, dan menggangu transport protein pada lapisan dalam sel.Tanin juga mempunyai target pada polipeptida dinding sel sehingga pembentukan dinding sel menjadi kurang sempurna. Hal ini menyebabkan sel bakteri menjadi lisis karena tekanan osmotik maupun fisik sehingga sel bakteri akan mati. Kompleksasi dari ion besi dengan tanin dapat menjelaskan toksisitas tanin. Mikroorganisme yang tumbuh di bawah kondisi aerobik membutuhkan zat besi untuk berbagai fungsi, termasuk reduksi dari prekursor ribonukleotida DNA. Hal ini disebabkan oleh kapasitas pengikat besi yang kuat oleh tanin [20]. Kuinon memiliki kisaran antimikroba yang sangat luas karena selain merupakan sumber radikal bebas, juga dapat membentuk kompleks dengan asam amino nukleofilik dalam protein sehingga dapat menyebabkan protein kehilangan fungsinya.

\section{KESIMPULAN}

Ekstrak etanol kulit salak mengandung golongan senyawa alkaloid, flavonoid, polifenol, tanin, dan kuinon. Ekstrak kulit salak memiliki aktivitas antibakteri terhadap Salmonella typhi dan menghambat secara efektif pada konsentrasi $20 \%$.

\section{DAFTAR PUSTAKA}

[1] Nurina, C.I.E., Samingan, dan Iswandi, "Uji antimikroba ekstrak buah salak (Salacca edulis) terhadap bakteri Escherichia coli", Jurnal Biologi EdukasiEdisi 12, Vol.6, No.1, Hal. 19, 2014, [Online].Available: http://jurnal.unsyiah.ac.id/JBE/article/view/2271

[2] Kanon, M.Q., Fatimawali dan Bodhi, W., "Uji efektivitas ekstrak kulit buah salak(Salacca zalacca (Gaertn.) Voss) terhadap penurunan kadargula darah tikus putih jantan galur Wistar(Rattus norvegicus L.) yang diinduksi sukrosa", Jurnal Pharmacon, Vol.1, No.2, Hal. 53,2012,[Online].Available:http://ejournal.unsrat.ac.id/index.php/pharmacon/article/view/48 $\underline{6}$

[3] Dhyanaputri, I.G.A.S, Karta, I.W, dan Krisna, L.A.W, "Analisis kandungan gizi ekstrak kulit salak produksi Kelompok Tani Abian salak Desa Sabetan sebagai upaya pengembangan 
potensi pangan produk lokal”, Meditory, Vol. 4, No. 2, Hal. 93, 2016, [Online]. Available: http://ejournal.poltekkes-denpasar.ac.id/index.php/M/article/view/48/29

[4] Aziz, T., Shabrina, D., dan Pratiwi, R.N., "Penurunan kadar ffa dan warna minyak jelantah menggunakan absorben dari biji kurma dan kulit salak", Jurnal Teknik Kimia, Vol.22, No.1, Hal.43,2016,[Online].Available: http://ejournal.ft.unsri.ac.id/index.php/jtk/article/view/72/62

[5] Fitrianingsih, S.P., Lestari, F., Aminah, S., "Uji efek antioksidan ekstrak etanolkulit buah salak (Salacca zalacca (Gaertner) Voss) dengan metode peredaman DPPH", Pros. Seminar Nasional Penelitian dan PKM Sains, Teknologi, dan Kesehatan,Vol. 4, No. 1, Hal.53,2014,[Online].

Available:http://proceeding.unisba.ac.id/index.php/sains_teknologi/article/view/538

[6] Pratiwi, I., "Uji Antibakteri Ekstrak Kasar Daun Acalypha indica Linn. terhadap Bakteri Salmonella choleraesuis dan Salmonella typhi", Skripsi, Program Sarjana Sains, Universitas Sebelas Maret, 2009, Surakarta.

[7] Brooks, G.F., Carroll, K.C., Butel, J.S., Morse, S.A., and Mietzer, T.A., “Jawetz, Melnick, \& Adelberg: Mikrobiologi Kedokteran”, Penerbit Buku Kedokteran EGC, 2010, Jakarta, 89-94.

[8] Syahrurachman, A., Buku Ajar Mikrobiologi Kedokteran, Binapura Aksara, 1994, Jakarta, 168-169

[9] Santoso, D., Khotimah, S., Andriani, "Uji aktivitas antibakteri ekstrak kasar biji buah langsat (Lansium domesticum Cor.) terhadap Salmonella typhi", Jurnal Mahasiswa PSPD FK Universitas Tanjungpura, Vol.3, No.1, 2015, [Online]. Available:https://jurnal.untan.ac.id/index.php/jfk/article/view/16695

[10] Whardhani, R.A.P dan Supartono, "Uji Aktivitas Antibakteri Ekstrak Kuli Buah Rambutan (Nephelium lappaceum L.) pada Bakteri”, Indonesia Journal of Chemical Science, Vol. 4, No. 1,2015

[11] Morgan, Michelle. "Ethanol in Herbal Medicine". Mediherbal phytotheraphist's perspective, 129, 2009.

[12] Khotimah, K., Skrining fitokimia dan identifikasi metabolit sekunder senyawa karpain pada ekstrak metanol daun Carica pubescens L.\& K. Koch dengan LC/MS (Liquid Chromatograph-tandem Mass Spectrometry), Skripsi, Program Sarjana Sains, Universitas Islam Negeri Maulana Malik Ibrahim, 2016, Malang.

[13] Ashadi, Mulyani, B., Rahmawati, C.P., dan Setyowati, W.A.E, "Skrining Fitokimia dan Identifikasi Komponen Utama Ekstrak Metanol Kulit Durian (Durio zibethinus Murr.) Varietas Petruk", Seminar Nasional Kimia dan Pendidikan Kimia VI,275, 2014.

[14] Haryati, N.A., Saleh, C., dan Erwin, "Uji toksisitas dan aktivitas antibakteri ekstrak daun merah tanaman pucuk merah (Syzygium myrtifolium Walp.) terhadap bakteri Staphylococcusaureus dan Escherichia coli”, Jurnal Kimia Mulawarman, Vol.13, No.1, Hal. 37, 2015 ,

[Online]. Available:http://jurnal.kimia.fmipa.unmul.ac.id/index.php/JKM/article/view/43

[15] Lim SH, Darah I, Jain K. "Antimicrobial Activities of Taninns Extracted from Rhizophora Apiculata Barks", Journal Of Tropical Forest Science, Vol. 18, No. 1, 2006, Hal. 59-65.

[16] More S, Maldar NN, Bhamra P., "Antimicrobial Activity of Naphtyl Iso- Quinolone Alkaloids of Ancistrocladus heyneanus : I Extracted From Leaves", Pelagia Research Library, Vol. 3, No. 5, 2012, Hal. 2760-2765.

[17] Bhuiyan MNI, Chowdhury JU, Jarip B., "Chemical components in volatile oil from Blumea balsamifera (L.)", DC. J Bangladesh, Vol. 38, No. 1, 2009, Hal. 107-110.

[18] Hassan S.M., "Antimicrobial Activities of Saponin-Rich Guar Meal Extract", Poultry Science, 2008, Texas.

[19] Hyldgaard M, Mygind T, Meyer RL., "Essential Oils in Food Preservation: Modeofaction, Synergies, and Interactions with Food Matrix Components". Frontiers in Microbiology, Vol. 3, No. 12, 2012, Hal. 1-24. 
[20] Rijayanti, R.P., Uji aktivitas antibakteri ekstrak etanol daun mangga bacang (Mangifera foetida L.) terhadap Staphylococcus aureus secara in vitro, Skripsi, Program Studi Pendidikan Dokter, Universitas Tanjungpura, 2014, Pontianak 